\title{
Interplay between innate and adaptive immunity in the development of non infectious uveitis
}

\author{
François Willermain(1), James T Rosenbaum(2), Bahram Bodaghi ${ }^{(3)}$, Holly L Rosenzweig ${ }^{(2)}$, \\ Sarah Childers ${ }^{(2)}$, Travis Behrend ${ }^{(2)}$, Gerhild Wildner ${ }^{(4)}$, and Andrew D Dick ${ }^{(5),(6)}$ \\ (1) Department of Ophthalmology, CHU St-Pierre and Brugmann and IRIBHM, Campus Erasme, \\ Université Libre de Bruxelles, Belgium \\ (2) Casey Eye Institute, Oregon Health \& Science University, Portland, Oregon \\ (3)Department of Ophthalmology, APHP, Pitie-Salpetriere Hospital, Paris, France \\ (4)Section of Immunobiology, Dept. of Ophthalmology, Clinic of the University of Munich, Munich, \\ Germany \\ ${ }^{(5)}$ School of Clinical Sciences, Academic Unit of Ophthalmology, University of Bristol, UK \\ (6) National Institute for Health Research-Biomedical Research Centre, Moorfields Eye Hospital \\ NHS Foundation Trust and UCL Institute of Ophthalmology, UK
}

\begin{abstract}
In vertebrates, the innate and adaptive immune systems have evolved seamlessly to protect the host by rapidly responding to danger signals, eliminating pathogens and creating immunological memory as well as immunological tolerance to self. The innate immune system harnesses receptors that recognize conserved pathogen patterns and alongside the more specific recognition systems and memory of adaptive immunity, their interplay is evidenced by respective roles during generation and regulation of immune responses. The hallmark of adaptive immunity which requires engagement of innate immunity is an ability to discriminate between self and non-self (and eventually between pathogen and symbiont) as well as peripheral control mechanisms maintaining immunological health and appropriate responses. Loss of control mechanisms and/or regulation of either the adaptive or the innate immune system lead to autoimmunity and autoinflammation respectively. Although autoimmune pathways have been largely studied to date in the context of development of non-infectious intraocular inflammation, the recruitment and activation of innate immunity is required for full expression of the varied phenotypes of noninfectious uveitis. Since autoimmunity and autoinflammation implicate different molecular pathways, even though some convergence occurs, increasing our understanding of their respective roles in the development of uveitis will highlight treatment targets and influence our understanding of immune mechanisms operative in other retinal diseases. Herein, we extrapolate from the basic mechanisms of activation and control of innate and adaptive immunity to how autoinflammatory and autoimmune pathways contribute to disease development in non-infectious uveitis patients.
\end{abstract}

(C) 2011 Elsevier Ltd. All rights reserved.

Corresponding author: François Willermain, Dpt of Ophthalmology CHU St-Pierre and Brugmann, 322 rue haute 1000 Bruxelles, Belgium.fwillerm@ulb.ac.be..

Publisher's Disclaimer: This is a PDF file of an unedited manuscript that has been accepted for publication. As a service to our customers we are providing this early version of the manuscript. The manuscript will undergo copyediting, typesetting, and review of the resulting proof before it is published in its final citable form. Please note that during the production process errors may be discovered which could affect the content, and all legal disclaimers that apply to the journal pertain. 


\section{Introduction}

"Nothing in biology makes sense except in the light of evolution". This citation of Theodosius Dobzhansky is germane to immunity, inflammation and the pathogenesis and therapeutic targets in ocular inflammatory diseases. In this context, our immune system has developed alongside the diversity of life forms and biological organisms. Maintaining organ and tissue function is dependent upon co-existing with a large genomic array of microbial commensals, whilst concomitantly retaining the capability of responding to pathogenic microbes (Lee and Mazmanian, 2010). For example, early life colonisation by bacteria generates host-microbe relationships that do not result in disease - immune tolerance. The corollary is that the majority of host-bacterial interaction is symbiotic and actively contribute to overall homeostasis (figure 1) (Casadevall and Pirofski, 2000). Both innate and adaptive immune mechanisms govern such capability. However, a risk of the adaptive immunity is an abnormal response against self protein, a potential requisite to the development of autoimmunity. With respect to the fact that adaptive and innate immunity rely on, at least initially, different molecular mechanisms, their associated diseases, respectively autoimmunity and autoinflammation, arguably also remain distinct. Whereas with reference to ocular disease, the pathways leading to autoimmunity have been most studied where although it remains largely conjecture as to a potential autoantigen (see section 5), the prominence of the recruitment and activation of innate immunity is increasingly recognized and moreover is arguably requisite for full expression of phenotypes of non-infectious uveitis we observe, and certainly experimentally. To back up such experimental findings clinically, a common occurrence during relapses of uveitis (although not exclusive), is the presence of non-ocular infection, even if not manifest clinically. In this review, we highlight the basic principles of adaptive and innate immunity and how immune mechanisms (autoimmunity versus autoinflammation) contribute to disease development in non infectious uveitis patients.

\section{Definition of non infectious uveitis}

Currently we define uveitic disorders purely on their clinical phenotype. This classification is undergoing further refinement involving consensus opinion, which is undoubtedly appropriate for clinical outcome studies and clinical trials, but does not fully acknowledge either commonality or diversity of immunopathogenesis (Jabs et al., 2005). Arguably and pre-emptively, we classify clinically intraocular inflammation as either infectious, where there is an obvious infectious aetiology, for example bacterial endophthalmitis, toxoplasmosis or herpetic retinopathies (Caspi, 2010; Dick et al., 2008), or non-infectious, where the aetiology is presumed to be autoimmune in nature. With respect to autoimmunity, an autoantigen has to be implicated generating accordingly antigen-specific $\mathrm{T}$ cell response or pathogenic autoantibodies or both. Whilst this has been implicated for intraocular inflammation, retinal specific $\mathrm{T}$ cell responses are also present in non-uveitic controls and we as yet do not know if such responses are pathogenic (Hirose $\mathrm{S}$ et al., 1988; Nussenblatt et al., 1980; Opremcak et al., 1991; Takeuchi et al., 2010; Yamamoto et al., 1993). Enticingly and in support is recent data showing in humanized mouse models detection of MHC Class II restricted S-Ag-specific $\mathrm{CD}^{+}{ }^{+} \mathrm{T}$ cells, similar to tetramer-positive cells in peripheral blood of a uveitis patient (Mattapallil et al., 2011). In order to activate an autoimmune response the autoantigen has to most commonly be recognised in the context of a restricted MHC class II antigens and specific TCR+ T cells. Genetic studies have highlighted this link, as illuminated by their HLA-DR associations, supporting the evidence that many of the uveitic disorders are likely to have an autoimmune component (Martin et al., 2003). Moreover, expression of disease is also governed by the multitude of immune related polymorphisms, most frequently in the inflammatory cytokine genes (Wallace and 
Niemczyk, 2011), and exemplified by the recent genome-wide association studies on Behcet's disease (Mizuki N et al., 2010; Remmers et al., 2010).

Autoinflammation is a term coined to describe disorders that arise from a dysregulation of innate immunity. For example, the understanding of the genetic and immunological basis of human periodic fever syndromes, in particular cryopyrin-associated periodic syndromes (CAPS), has led to important new insights into the pathogenesis of monogenic and complex interleukin-1beta-associated autoinflammatory diseases (Masters et al., 2009). This review will show evidence of such mechanisms operative during intraocular inflammation, as well as the relationship between potential infectious drive (activation of innate immunity) and development of autoimmunity. We will in particular develop the notion that it is likely that both autoimmune and autoinflammatory mechanisms participate and converge during the development of non-infectious uveitis.

The general tenet of immune mechanisms during inflammatory disease (autoimmune and autoinflammatory) has arisen from principles of immune privilege (Billingham et al., 1953) and Matzinger's danger theory (Matzinger, 1994). The concepts go beyond the ability to maintain tolerance to self via both central thymic and peripheral tolerance mechanisms and now include evidence of how the two arms of the immune system, innate and adaptive immunity, respond together to signals that may cause harm for example, infection and surgical wounds, whilst preserving the ability to not respond to self-antigen. This requires cross-talk between both innate and adaptive immunity and also brings into play tissue responses that control overactive immune responses (Matzinger and Kamala, 2011). Therefore, again with respect to the eye, maintaining tolerant responses to innate signals, as well as autoimmune $\mathrm{T}$ cell responses, is paramount.

\section{Innate and adaptive immunity}

\subsection{Innate immunity}

An innate immune system provides an immediate host immune response to infectious agents and relies on the expression of germline-encoded receptors for their detection. Those receptors recognize microbial-specific molecular patterns (pathogen associated molecular patterns, PAMPs), generally motifs shared by large groups of microorganisms. This clearly makes sense in an evolutionary perspective, since those molecular structures are essential for the survival of microbes and are thus less likely subject to conformational changes or mutations (Medzhitov and Janeway, 1997). Besides, this strategy has not only been adopted in the animal kingdom, but in plants as well (Ronald and Beutler, 2010).

Different families of PAMPs receptors have been described (table 1 and figure 2). The Tolllike receptors (TLR) and C-type lectins (CTL) are expressed on plasma membranes and endosomes while RNA and DNA sensors are present in the cytoplasm. TLR comprise different members which are activated by bacterial cell wall components or nucleic acids from bacteria or viruses and are expressed on innate immune cells, but also on $\mathrm{T}$ and $\mathrm{B}$ lymphocytes and on endothelial cells and keratinocytes for example (Kawai and Akira, 2010). CTL bind mannose, fucose and glucan and are mainly expressed by dendritic cells and macrophages. Receptor ligation leads to pathogen internalization and is an important way to deliver antigen for presentation (Geijtenbeek and Gringhuis, 2009). In addition to TLR, viral nucleic acids can also be detected by cytoplasmic sensors of the retinoic acidinducible gene-I (RIG-1) like receptor (RLR) family. Once activated by their ligands, TLRs activate the NF-kB and MAPK pathways which drive the liberation of proinflammatory cytokines. Transcription of members of the interferon regulatory factor (IRF) and subsequent production of type I interferon are also central features of this series of receptors. Intracellular detection of microbial motifs is not only restricted to TLR or RIG but is also a 
function of another group of PAMPs receptors, the NOD-like receptors (RLR). Based on phylogenetic analysis, NLR can be further classified into 3 subfamilies: NODs, NLRPs and IPAF. Upon activation, NOD1 and NOD2 oligomerise and, as other PAMPs receptors, activate the NF-kB and MAPK pathways. However, the upstream signals induced by other NLR differ from other PAMPs receptors. Hence, activation of some NLR induces the formation of large scaffolds of proteins, called inflammasomes, which will activate caspase-1 and promote the extracellular release of interleukin-1 (IL-1) and interleukin-18 (IL-18) (Schroder and Tschopp, 2010), ascribed as a canonical feature in the pathology of autoinflammatory diseases (see below).

\subsection{Adaptive immunity}

An explosion of life-forms diversification and speciation occurred during the Cambrian period, around 550 million years ago. At this time a new way to sense and eliminate pathogen was created, which basically offers the opportunity to distinguish self from nonself. It relies on the expression of an almost unlimited number of specific receptors on lymphocyte clones. In jaw vertebrates, $\mathrm{T}$ lymphocytes recognize processed peptide fragments presented by specialized antigen presenting cell through the expression of $\mathrm{T}$ cell receptors (TCR) while B lymphocytes receptors (BCR) detect intact molecules. TCR and $\mathrm{BCR}$ can recognize an almost unlimited set of antigens, and are generated by mixing and matching variable $(\mathrm{V})$, diversity (D) and joining (J) gene segments in a process called VDJ recombination (Cooper and Alder, 2006). This highly complex process renders possible the generation of an almost unlimited number of antigen receptors with a limited set of genes and is largely dependent on the expression of the lymphocyte specific recombination activating genes RAG1 and RAG2. Interestingly, RAG genes expression in jaw vertebrates is likely to be the result of the landing of a transposable element (genomic element that have the ability to move from one chromosomal location to another) into their genome (Market and Papavasilliou, 2003). In this context, it is important to note that jawless vertebrates use RAG-independent gene recombination mechanisms to generate variable lymphocyte receptors on lymphocyte like cells (Guo al., 2009). Such example of convergent evolution clearly suggests that, at least in vertebrates, adaptive immunity provides an added value to the organisms. Interestingly, it has been recently proposed that the benefit of the adaptive immune system is mainly to offer the possibility to distinguish between commensal microbes and pathogens rather than providing a better defense against invasive microorganisms (Hedrick, 2009). Hence, adaptive immunity would permit an ability to tolerate microbial residents which could result, for example, in access to new dietary components and a unique evolutionary advantage (Weaver and Hatton, 2009). However, the generation of this randomly generated vast repertoire of TCR and BCR implicate that cells with self-antigen recognising receptors are also produced with the potential risk of selfrecognition and organ damage. This danger is normally prevented by a step of selection during lymphopoiesis where autoreactive lymphocytes are deleted. This process, called central tolerance, is nevertheless imperfect, and autoreactive lymphocytes are present in healthy subjects and maintained quiescent by peripheral tolerance mechanisms. A notion therefore is that any perturbation of central and peripheral tolerance mechanisms leads to autoreactive lymphocytes activation and autoimmunity. In a more general setting, autoimmunity can be defined as an abnormal activation of the adaptive immune system, and thus differentiates pathogenesis of disease from those caused by autoinflammation.

\subsection{Contribution of innate immunity pathways to adaptive immunity}

A breakthrough in our understanding of the biology of the immune system was made when Charles Janeway proposed that one of the functions of the innate immune system was actually to give information about the source of the antigen (Janeway, 1989). The thesis predicted the existence of PAMPs receptors and postulated that activation of those receptors 
would help antigen presenting cells to distinguish between infectious and non infectious antigens. This hypothesis is now widely accepted and the role of PAMPs receptors in shaping the adaptive immune response has been further demonstrated (Palm and Medzitov, 2009). In this context, it has been shown, for example, that different TLRs, by differentially regulating IL-12 family members can direct adaptive immunity towards a Th1, Th2 or a Th17 response (Goriely et al., 2008). Hence, TLR activation not only provides information on the infectious nature of the antigen, but also, since different TLR are activated by different families of microbes, identifies with some precision the nature of that infection. This additional level of information is also found with other PAMPs receptors members like Dectin-1, which stimulate Th17 differentiation, and with cytosolic PAMPs receptors, which might even help the cell to discriminate between pathogen and symbionts (Palm and Medzhitov, 2009). Moreover, crosstalk between TLR and NLR has been described and offer further possibility to identify the origin of the antigen (Fritz et al., 2007).

Interestingly, Janeway's hypothesis has been extended to a more general danger model by Matzinger (Matzinger, 1994). In this danger theory, the signal that informs the cell on the nature of the antigen is not restricted to PAMPs but broadened to molecules produce during tissue injury and cell death. In reference to PAMPs, the term damage-associated molecular pattern (DAMPs) was introduced to define this new family of endogenous danger signals, but alarmins is also often used. Accordingly, a series of endogenous molecules (e.g. monosodium urate crystals, high mobility group box 1 protein or nucleotide) have been found to have adjuvant or proinflammatory properties (Kono and Rock, 2008). Remarkably, it has been demonstrated that some DAMPS are recognised by PAMPs receptors. Interestingly, in parallel, recent data have elegantly demonstrated that non hematopoietic cells also play an important role in sensing danger signals and shaping the adaptive immune response. Fritz et al. (2007) have for example demonstrated that non hematopoietic cells are key in triggering the Nod1-mediated Th2 responses. Finally we have a picture forming on how the innate immune system, by translating the context of antigen uptake and presentation, will eventually drive adaptive immune response and its consequent behaviour and function. This has most recently been described in the context of PAMPs receptors signalling and differentiation of Th1/Th17 cell and their development (Krausgruber et al., 2011).

\section{Autoinflammation and uveitis}

\subsection{Autoinflammation and experimental uveitis}

A variety of circumstantial observations suggests that the innate immune system is very important in the development of uveitis. These observations include: 1) Most eye tissues (cornea, uvea and retina) expresses TLRs (Chang et al., 2006). NOD1 and NOD2 are also strongly expressed (Rosenzweig et al., 2008; Rosenzweig et al., 2009). Accordingly, a variety of synthetic TLR agonists will induce cytokine synthesis and uveitis when injected locally in a mouse eye (Rosenzweig, Allensworth, Rosenbaum, manuscript in preparation). The prototypic activator of TLR in the eye is endotoxin and this initiator of inflammation is discussed more fully below. 2) Most models of autoimmunity in general and uveitis in particular require an adjuvant and most adjuvants act by activating a TLR or NLR; 3) The uveal tract includes cells such as macrophages and dendritic cells, which are known to participate in innate immunity (McMenamin et al., 1994); 4) An autosomal dominant form of uveitis, Blau syndrome, is caused by mutations in an NLR family member, namely NOD2 (Miceli-Richard et al., 2001). The NOD2 protein recognizes muramyl dipeptide, a component of bacterial cell walls. 5) Polymorphisms or copy number of TLR genes or other genes involved in microbial recognition affect susceptibility to autoimmunity. For example, CARD9 is critical in the signaling initiated by Dectin-1 activation. Rare mutations in CARD9 cause chronic fungal infection (Glocker et al., 2009). Polymorphisms of CARD9 
affect susceptibility to ankylosing spondylitis and Crohn's disease, two systemic diseases associated with uveitis (Pointon et al., 2011; Zhernakova et al., 2008). 6) Bacteria have been implicated in the causation of a number of the systemic diseases associated with uveitis including inflammatory bowel disease, sarcoidosis, Behcet's disease, and psoriatic arthritis. (Friswell et al., 2010; Huerta et al., 2007; Noah, 1990; Song et al., 2005; Strober, 2010; Yanagihori et al., 2006). 7) A footpad or tail injection of killed mycobacteria in Lewis or Sprague Dawley rats stimulates the innate immune system and induces both uveitis and arthritis (Petty et al., 1989).

A.C. Woods was one of the first to suspect that the innate immune system contributed to uveitis, although his work was prior to the conceptualization of innate immunity. Woods injected rabbits intravenously with supernatant from Gram negative bacterial cultures and noted that eyes became red (Woods, 1916). Endotoxin or lipopolysaccharide is the major component of the outer cell wall of Gram negative bacteria. In fact, the LPS is responsible for the staining that identifies the microbe as Gram negative. Thirty years ago, Rosenbaum and colleagues described an acute anterior uveitis in rats subsequent to the injection of endotoxin in a footpad (endotoxin induced uveitis, EIU) (Rosenbaum et al., 1980). Forrester and colleagues contemporaneously described uveitis in rats that received LPS locally in the eye (Forrester et al., 1980). The route of injection was not critical as the LPS could also be given subcutaneously, intravenously, or intraperitoneally. The source of the LPS was not critical and could be from a pathogenic or non-pathogenic isolate. Most strains of rats were susceptible. The dose of LPS needed to induce uveitis did not produce histological abnormalities in other organs. The inflammation was transient with the infiltrate peaking about 24 hours after the LPS application and usually disappearing by 72 hours. If the LPS was injected daily, the rat became tolerant and the cellular infiltrate did not persist. The posterior portion of the eye is also affected by LPS with changes such as increased adhesion molecule expression in retinal vessels, but the cellular infiltrate is not as marked (Koizumi et al., 2003).

Although TLR4 had not been described when EIU was first reported, much is now known about TLR4. A unique aspect of TLR4 is that it can signal through either of two adaptor molecules, MyD88 or TRIF (O'Neill, 2008). In some cells, both adaptor molecules participate in signalling while some cells such as neutrophils signal preferentially through a single adaptor molecule (Tamissia et al., 2007). Data indicate that the eye can synthesize cytokines like IL-6 dependent on the MyD88 pathway as well as cytokines such as RANTES or MCP-1 which are dependent on the TRIF pathway (Kezic et al., 2011). However, studies with either MyD88 or TRIF knockout mice indicate that the MyD88 pathway is the one critical for the cellular infiltrate. Rosenbaum's lab has conducted studies with chimeric mice using bone marrow from mice that lack a functional TLR4 (Kezic et al., 2011). Surprisingly mice with bone marrow cells that lack a functional TLR4 still respond to LPS, although the majority of the dendritic cells and macrophages in the uveal tract of these mice should be unable to respond to LPS. This observation suggests that non bone marrowderived cells such as vascular endothelial cells or pigmented epithelial cells are the ocular cells most responsible for EIU.

The uveal tract of mice and rabbits is also very sensitive to LPS, but a systemic injection induces much less of a cellular infiltrate (Rosenbaum et al., 1980). EIU is currently frequently studied in mice as this species has become the preferred one for studies on the immune system. In order to induce a marked cellular infiltrate, nanogram quantities of LPS are injected directly into the eye, usually intravitreally. While most inflammation occurs within the first 4 to 48 hours after a systemic injection, a later wave of inflammation about 5 to 7 days after the injection has also been described (Kozhich et al., 2000). Our own studies on the effects of intraperitoneally injected LPS in mice suggest that the failure of this route 
to induce a cellular response is due to the LPS causing a transient desensitization of the leukocytes such that they are unable to extravasate (Rosenbaum et al., 2011). A similar phenomenon has been described when LPS is injected locally in tissues other than the eye (Khan et al., 2005)

The relevance of EIU to uveitis in patients remains speculative. Using human explant cultures, we have demonstrated that $10 \mathrm{pg} / \mathrm{ml}$ of LPS will induce a measurable synthesis of interleukin- 8 by the human iris (figure 3 ). The retina is also very sensitive to LPS in vitro, but not quite as sensitive as the iris as shown in the figure. Although endotoxemia occurs during gram negative sepsis, iritis is not a recognized concomitant of septicemia. On the other hand, Gram-negative bacterial infections by specific strains of Salmonella, Yersinia, Campylobacter, or Shigella are known to trigger the HLA B27-associated disease, reactive arthritis (formerly Reiter's syndrome). Data enticingly generates a notion that both ankylosing spondylitis and inflammatory bowel disease, two systemic illnesses that are associated with anterior uveitis, might be due to endogenous bowel flora (Friswell et al, 2010; Strober, 2010; Taurog et al., 1994). Although the sensitivity of the rodent uveal tract to endotoxin and the above observations might be coincidence, the likelihood is that the observations are related and we just lack the insight to link these findings.

Although bacterial infections are not always evident as triggers for uveitis, many argue that endogenous substances can also trigger innate immunity through activation of TLRs (Erridge, 2010). For example, hyaluronic acid, certain heat shock proteins, tenascin C, microcrystalline, and S100A8/A9 might activate TLR4. Since these molecules are not derived from pathogens, they cannot be labeled PAMPs and as mentioned before are known either as DAMPs (danger associated molecular patterns) or alarmins. Those who doubt the existence of endogenous TLRs argue that it is unlikely that a receptor could recognize such a vast array of different substances and that the most likely explanation is that LPS binds to these substances and might be potentiated by this binding. One publication indicates that S100A8/A9 can induce uveitis in rats and our own unpublished observations are similar in mice (Chi et al., 2007). While much remains to be learned about the mechanism by which an endogenous TLR ligand activates the receptor, it does seem likely that a microbial product is not essential for the activation of the innate immune system. Although corroborative evidence would be further achieved via interrogation of PAMPs and DAMPs induced uveitis model in RAG - $/-$ mice, the evidence remains and emphasizes that activation of the innate immune system may induce uveitis mediated via PAMPs receptors and subsequent inflammasome activation (autoinflammation), even in the absence of infective agents.

\subsection{Uveitis in patients with autoinflammatory syndromes}

4.2.1. Introduction-Autoinflammatory syndromes are driven by the innate immune system, comprise a wide spectrum of conditions, and represent both hereditary and multifactorial disorders (table 2). Clinical findings are nonspecific. Common systemic findings are fever, abdominal pain, arthritis, cutaneous lesions, hearing loss and CNS involvement. Main ocular findings of autoinflammatory syndromes are listed in table 3 . The majority of the rare disorders described are monogenic. However, the more common inflammatory systemic diseases that may exhibit ocular inflammation include Crohn's disease and ulcerative colitis representing polygenic autoinflammatory diseases. In addition Behçet's syndrome, ankylosing spondylitis and psoriatic arthritis represent mixed pattern diseases involving both $\mathrm{MHC}$ association and restriction implicating antigen specificity and $\mathrm{T}$ cell driven as well as requiring autoinflammatory components.

4.2.2 Blau syndrome-Blau syndrome is an autosomal dominantly inherited syndrome, characterized by an early-onset granulomatous arthritis, recurrent uveitis, cranial 
neuropathies, exanthema and camptodactyly (Kurokawa, 2003)(table 3). Early-onset sarcoidosis (EOS) is another auto-inflammatory condition similar to Blau syndrome regarding clinical and pathologic features and response to treatment and may indeed represent a spectrum with respect to polymorphic changes in the innate pattern recognition receptors, including the NOD2 gene. The main difference that currently clinically differentiates between the two conditions is the absence of family history of the disease in EOS. The typical age at onset is less than 4 years. Although the disease is classically characterised by the triad of dermatitis, arthritis and uveitis, a recent Spanish study observed uveitis in only $50 \%$ cases. Interestingly, even in the complete forms, the triad is usually not present at the onset of the disease. In children with ocular involvement, recurrent bilateral uveitis is a frequent feature. Panuveitis seems to be more common than anterior uveitis. Conjunctivitis, cataract, secondary glaucoma, multifocal choroidal granuloma, corneal opacities and retinal detachment are other associated findings (Arostegui et al., 2007; Jabs et al., 1985; Kurokawa et al., 2003; Latkany et al., 2002). When present, ocular involvement is the most refractory to conventional treatments and the main cause of morbidity.

4.2.3 Cryopyrin-associated periodic syndrome-The cryopyrin-associated periodic syndrome (CAPS) is a rare hereditary auto-inflammatory syndrome including three phenotypes: familial cold auto-inflammatory syndrome (FCAS), Muckle-Wells syndrome (MWS), and neonatal onset multisystem inflammatory disease / chronic infantile neurologic cutaneous and articular syndrome (NOMID/CINCA). These cryopyrinopathies are no more considered as distinct conditions but different severities of the same disease and CAPS patients often show an overlap of the 3 syndromes. FCAS is the mildest phenotype and ocular involvement is usually absent. Muckle-Wells syndrome (MWS) is the intermediate phenotype, characterized by renal amyloidosis, sensorineural hearing loss, and conjunctivitis. In MWS anterior uveitis may occasionally be seen, but posterior segment involvement is very rare (Shakeel and Gouws, 2007).

CINCA syndrome is the most severe phenotype of cryopyrin-associated periodic syndrome comprising arthritis, chronic urticaria and meningitis (figure 4). The disease starts at 6 weeks with a rash, followed by fever, meningitis, joint disorders, vision and hearing loss and mental retardation. The course of the disease is more chronic than recurrent. Dolfus et al. (2000) have reported on a series of 31 children with a mean age of 4.5 years at the onset of ocular disease. Optic disc abnormalities have been identified in $83 \%$ of cases, representing the major clinical finding with papillitis (42\%), papilledema (23\%) and optic atrophy (29\%). Therefore, fundus examination remains the key feature in the identification of ocular involvement. Optic disc drusen has to be considered as a differential diagnosis and B-scan is the best investigation to perform in atypical cases. Monitoring of the visual field is proposed for children with papilledema. The other clinical findings involving the posterior segment are vitritis (13\%), vasculitis (10\%), macular edema (13\%), focal chorioretinitis (3\%). Mild to moderate anterior uveitis is observed in $52 \%$ of cases but chronic conjunctivitis (48\%), corneal involvement with band keratopathy (26\%), stromal infiltrates (23\%), corneal neovascularization (10\%), cataract (16\%) and dry eye (13\%) are other potential ocular findings (Terrada et al, 2011). Sight-threatening complications have been noted in $26 \%$ of cases.

The level of IL-1-beta production is increased in NOMID/CINCA, encouraging the use of biological agents. The long-term efficacy and safety of anakinra, an IL-1 inhibitor has been recently reported, corroborating the earlier case report finding response of uveitis following switching to anakinra therapy (Neven et al., 2010, Teoh et al., 2007). In this study, 10 children ( 3 male, 7 female) were treated with anakinra with a follow-up ranging from 26 to 42 months. Severe papilledema was present in 7 cases. Visual impairment due to partial optic atrophy was noted in 2 patients. Recurrent episcleritis was reported in one patient. 
Interestingly, papilledema normalized in 3 patients and dramatically improved in the 4 others. Persistence of headaches was associated with persistence of papilledema. CNS involvement was controlled with higher doses of anakinra with a subsequent improvement of papilledema. The efficacy of anakinra on resolution of papilledema is demonstrated in Fig 5 .

4.2.4 Treatment strategies-Before the era of biologic agents, different antiinflammatory drugs, immunosuppressants such as methotrexate, cyclosporine, azathioprine and cyclophosphamide have been used for the treatment of auto-inflammatory conditions. However, results were usually disappointing. The introduction of TNF alpha blockers was a major progress in conditions such as Crohn's disease and Behçet's disease. Therefore, it was important to develop new targeted strategies. The interleukin-1 receptor antagonist (anakinra) showed a significant efficacy in patients with CAPS. The most common side effects are injection site reactions and upper respiratory infections. The main limitation for the use of anakinra was its short half-life imposing a daily use. Because of the complexity of its receptor system, the inhibition of IL-1 was very difficult to achieve. This spurred the development of cytokine trap technology resulting in rilonacept (interleukin 1-trap), currently approved for the treatment of CAPS. With a longer half-life than anakinra, weekly subcutaneous injections became possible. Canakinumab is an IL-1 beta fully human, monoclonal antibody, which is specific for IL-1beta and not other members of the IL-1 family. The longer half-life allows an injection every 8 weeks in patients with CAPS. Most patients did not report any injection site reactions. New strategies including Caspase-1 inhibitors which act upstream of the IL-1 beta cascade show promising results in vitro and in experimental models (Yu and Leslie, 2011).

4.2.5 Crohn's disease and Behçet's disease-As potential canonical autoinflammatory conditions, two major groups of diseases must be considered. Gastrointestinal involvement is very common in Crohn's disease (CD) but may also be observed in Behçet's disease (BD). Non-granulomatous uveitis is a classical clinical feature, more frequently anterior in CD and posterior or pan in BD. NOD2/CARD15 seems to be the major susceptibility gene for CD. About 20 to $40 \%$ of all patients, depending on the genetic background, carry variants of this gene in contrast to $10-15 \%$ in the healthy population. On the basis of certain clinical similarities, its episodic nature and the importance of granulocyte activation in its pathogenesis, $\mathrm{BD}$ incorporates autoinflammatory mechanisms in the pathogenesis and expression of disease and justifiably represents a condition on the spectrum of autoinflammatory disorders (Gul A, 2005). Both conditions are very efficiently controlled by anti-TNF-alpha agents (Lee and Dick, 2010; Silva et al., 2010). The role of microbial pathogens is also implicated in the pathogenesis of both conditions, even though strong evidence is lacking in $\mathrm{BD}$, but remains to support the prominence of innate immune activation in the immunopathogenesis. The importance of responses to intestinal bacteria in CD is emphasized by the association with the NOD2 gene, which encodes an intracellular sensor of peptidoglycan, a component of bacterial cell walls and its significance elaborated in the previous section. Previously considered as an autoimmune disease, the designation of $\mathrm{CD}$ as an autoinflammatory disorder in particular, is increasingly supported by data that corroborates the altered or dysregulated host response to intestinal microbiata in development of clinical disease. 


\section{Interplay between innate and adaptive immunity in the development of non infectious uveitis}

\subsection{Evidence supporting the role of autoreactive lymphocytes activation in non infectious uveitis}

Supporting an autoimmune aetiology for non infectious uveitis, various groups have demonstrated that $\mathrm{T}$ lymphocytes from patients with uveitis proliferate in response to retinal antigens, although and perhaps not surprisingly retinal specific autoreactive lymphocytes are also found in the circulation of unaffected individuals (Hirose et al., 1988; Nussenblatt et al., 1980; Opremcak et al., 1991; Yamamoto et al., 1993). Those seminal data have been confirmed by more recent studies which support the notion that central tolerance does not prevent retinal autoreactive $\mathrm{T}$ lymphocytes being present in healthy subjects and thus must evoke peripheral tolerance mechanisms to prevent disease, as well as an ability to generate disease (Caspi, 2011; Takeuchi et al., 2010). The classical view is that in uveitis patients with potential genetic predilection, environmental factors trigger the activation of retinal specific autoreactive lymphocytes which as a result, penetrate the blood retinal barrier and promote intraocular inflammation. In experimental animals, such autoreactive lymphocytes (to a variety of retinal antigens) can be readily activated by standard immunization protocols.

\subsection{Role of innate immunity in autoreactive lymphocytes activation during experimental autoimmune uveitis (EAU)}

Uveitis can be induced in susceptible animals by immunization with different ocular antigens. Historically, antigens were first prepared from uveal extracts until the group of Wacker discovered that retinal antigens were highly pathogenic. Those works led to the identification of the two main retinal antigens S-antigen (S-Ag) and IRBP (interphotoreceptor retinoid-binding protein) and have been further refined (Caspi, 2011; Wacker and Lipton, 1965; Wacker, 1991). The immunization protocol is well standardized and consists in subcutaneous injection of the antigen emulsified in complete Freund adjuvant (CFA), supplemented with mycobacterial antigens (Caspi, 2010). Moreover, an additional intraperitoneal injection of pertussis toxin is also frequently performed simultaneously. Those technical aspects are often hidden in the material and methods section but are nevertheless required, in certain models, for full disease development and hence further emphasises the need to mobilize both innate and acquired immunity to generate autoimmunity, and in particular a drive through PAMPs, that implicates concomitant infection.

Adjuvants are classically used to boost immune responses and their effects rely on two main properties. Firstly, adjuvants act as depots that optimize antigen concentration and delivery. Secondly, adjuvants stimulate the innate immune system. This effect is an indispensable step for the full activation of adaptive immunity and definitively gives an autoinflammatory component to EAU. However, it is still unknown which PAMPs receptors mediates the activation of innate immunity during EAU induction. Strikingly, it has been demonstrated that mice deficient in TLR2, TLR4 or TLR9 as well as double knock-out TLR2+4, TLR2+9, and TLR4+9 were fully susceptible to EAU (Fang et al., 2010; Su et al., 2005). However, activation of those receptors enhances EAU score. This suggests that those TLR play a redundant role in the adjuvant effect during EAU. Interestingly, MyD88- and IL-1Rdeficient mice are resistant to EAU induction (Su et al., 2005). Since inflammasome activation leads to IL-1 production, one might postulate that NLR could also play a role in the adjuvant effect during EAU. 
Altogether those data emphasize the importance of innate immunity in the induction of an adaptive autoimmune response during EAU. The induced retinal-specific autoreactive lymphocytes have been well characterized and are of the Th1 and Th17 subtypes. Interestingly, autoimmune uveitis can also be induced by a direct intraperitoneal adoptive transfer of those autoreactive lymphocytes in naïve animals, without the need of further adjuvants. This suggests that autoimmunity can alone induce experimental autoimmune uveitis, although the role of innate immunity in the adoptive transfer model of EAU remains to be determined. A formal demonstration of this point would require adoptive transfer experiments into PAMPs and DAMPs receptors (tissue specific) knock-out mice.

Nevertheless, those experimental data provide evidence that non infectious uveitis can be induced in susceptible animals by autoimmunity mechanisms (adoptive transfer model of EAU), autoinflammatory mechanisms (EIU) and a combination of both (classical EAU).

\subsection{Role of antigenic mimicry in the activation of autoreactive lymphocytes in non infectious uveitis}

In EAU autoreactive lymphocytes are activated in the periphery by immunization with retinal antigens, whereas the activation of the autoimmune response in human patients is obviously different. One attractive hypothesis to explain this pathological activation is related to antigenic mimicry, a phenomenon based on the natural cross-reactivity of $\mathrm{T}$ cell receptors. In this scenario $\mathrm{T}$ cells activated outside the eye can penetrate the blood-retinabarrier and cause intraocular inflammation due to stimulation of the $\mathrm{T}$ cell receptor with mimicry peptides from retinal autoantigens. The group of Wildner has described peptides from environmental antigens, which could cross react with retinal S-Ag peptide (PDSAg) due to amino acid sequence homologies (Wildner and Diedrichs-Mohring, 2003; Wildner and Diedrichs-Moehring, 2005). These peptides are from rotavirus (Rota) and from bovine milk casein (Cas). Both antigens normally enter the organism via the gastrointestinal tract, where they are first seen by the immune system. In these cases it is proposed that the autoimmune response against ocular antigen is induced in the gut by a viral infection or by an accidental adverse immune response to a harmless nutritional antigen like milk casein. The immune response to the pathogen rotavirus is desired, whereas nutritional proteins should normally be tolerated (oral tolerance). In the Lewis rat model of EAU the uveitogenicity of peptides Cas and Rota by subcutaneous immunization with peptides in complete Freund's adjuvant has been demonstrated. The disease was indistinguishable from EAU induced with S-Ag peptide PDSAg with respect to clinical and histological findings (Wildner and Diedrichs-Mohring, 2003).

Cross-reactivity of the pathogenic peptides Rota and Cas with ocular autoantigen PDSAg could be demonstrated with peptide-specific $\mathrm{T}$ cell lines. Rota-specific rat cell lines strongly proliferate in response to peptide PDSAg, while PDSAg-specific T cell lines respond to Rota with decreased proliferation. Cas-specific T cell lines crossreact with PDSAg, in contrast to PDSAg-specific lines, which barely recognize the peptide Cas. These observations point to a better presentation of the autoantigen peptide PDSAg on MHC class II or to a higher T cell receptor avidity compared to the environmental epitopes Rota and Cas, indicating that retinal peptide PDSAg might be a dominant epitope (Wildner and Diedrichs-Mohring, 2003; Wildner and Diedrichs-Möhring, 2004).

For casein protein it has been demonstrated that the natural, gastrointestinal process of antigen introduction is sufficient for induction of uveitis in rats. In this case cholera toxin was used as an adjuvant to promote Th1 polarisation. This adjuvant also enabled uveitis induction by feeding the animals with just $0.5 \mathrm{ml}$ bovine milk (figure 6). Finally, patients with autoimmune uveitis have enhanced antibody and $\mathrm{T}$ cell responses to Rota and Cas compared to healthy donors, which might be a hint that rotavirus infections or accidental 
immune defense against milk proteins could play a role for inducing or perpetuating uveitis in patients (Wildner and Diedrichs-Mohring, 2003; Wildner and Diedrichs-Möhring, 2004).

\subsection{Do we need infection to induce autoimmune uveitis?}

Antigen mimicry can elegantly explain why retinal autoreactive $\mathrm{T}$ cells can potentially be activated by environmental factors. However, as mentioned in section 3.3, stimulation of retinal specific auto- or cross-reactive lymphocytes requires also the presence of danger signals. In this regards infectious triggers have the potential to provide both, a cross-reactive antigen and also the danger signals through activation of PAMP's and DAMPs. In this context, one important example to discuss is the potential chronic infection or latency with Mycobacterium tuberculosis.

A third of the world's population has been exposed to M. tuberculosis and although tuberculosis remains a very significant health issue, the majority remain unaffected although persist as mantoux test positive (Dye et al., 1999; Flynn and Chan, 2001; Gupta V et al., 2007; Maartens and Wilkinson, 2007). Whether this means activity or latency or just immunological memory has yet to be clarified. Nevertheless, there remains complementarity with the animal models we have discussed and the need for mycobacterial adjuvants to induce disease (see above). Although tuberculosis is an archetypal pulmonary disease, $M$. tuberculosis can also infect the eye and initiate intraocular inflammation as a variety of phenotypes (Abu El-Asrar et al., 2010; Cutrufello et al., 2010; Gupta, A., et al., 2010). However, even when ocular tuberculosis is suspected, it is often very difficult to detect $M$. tuberculosis within the eye, either by culture or by PCR. The question therefore remains as to whether under such circumstances this clinical scenario ascribes an infective drive to generate autoimmunity. Data supporting this hypothesis have been described in some patients treated with Bacille Calmette Guérin (BCG) vaccines. BCG is an attenuated strain of Mycobacterium bovis, and its use as vaccine was discontinued in several countries due to its highly variable efficacy (Fine, 1995), while sometimes vaccination was burdened with severe side effects (Colditz et al., 1994; Hegde and Dean, 2005; Liberek et al., 2006; Rodrigues et al., 1993; Wilson et al., 1995). However, BCG is still widely and successfully used as local treatment for bladder carcinomas. Several cases of uveitis as side effects of BCG instillation are reported in the literature (Uppal et al., 2010). The group of Wildner described a patient who presented with bilateral granulomatous iritis 2 weeks after she developed cystitis from BCG-instillation to treat her bladder carcinoma. Her uveitis was easily controlled within a few weeks by local corticosteroids (Garip et al., 2009). Six weeks later PBMCs were tested for in vitro proliferation and cytokine secretion in response to tuberculin and retinal autoantigens. Strong proliferation and secretion of Th1-type cytokines (IL-2, IFN- $\gamma$, TNF- $\alpha$ ) as well as IL-6, IL-8 and MIP-1 $\alpha$ (CCL3) were detected in cultures stimulated with tuberculin, while the only retinal autoantigens tested that induced proliferation were IRBP and a peptide from retinal S-Ag. However, Th1 and inflammatory cytokines and chemokines were secreted after stimulation with both, S-Ag and IRBP and a set of their peptides as well as CRALBP (cellular retinal-binding protein), a recently described potential uveitogenic autoantigen (Deeg et al., 2007). Screening protein databases for sequence homologies of proteins from BCG and the recognized autoantigens and their peptides revealed numerous potential mimotopes (Garip et al., 2009). Based on those data, it has been speculated that BCG can induce $\mathrm{T}$ cell responses, which are crossreactive with epitopes from retinal autoantigens S-Ag, IRBP and CRALBP and thus direct the immune response to the eye, where these peripherally activated $T$ cells find their mimicry antigens. Altogether, those data and our knowledge about the role of CFA as danger signals might thus support the hypothesis that the chronic systemic, subclinical, infection with $M$. tuberculosis would not only provide cross-reactive antigens, but also essential danger signals, required for the activation of retinal specific autoreactive lymphocytes. It is thus 
likely that in certain genetically predisposed patients with latent tuberculosis the uveitis is actually non infectious and merely driven by consequential autoimmune mechanisms (Doycheva et al., 2010).

\subsection{Regulation of the adaptive immune system by innate immunity: Tissue responses regulating inflammation}

Much of our concepts of putative autoimmune uveitis are derived from studies of animal models, including EAU (Caspi, 2011; Forrester et al., 2008, Forrester et al., 2010). As mentioned earlier, EAU is mediated by both generation of antigen specific Th1 (IFN gamma +) and Th17 (IL-17+) CD4+ T cells (Kerr et al., 2008). Two observations should be noted: firstly, although there are spontaneous models of non-infectious intraocular inflammation (Devoss J et al., 2006; Lambe et al., 2007), most disease models require concomitant activation of innate immunity within their immunization protocols that include, for example, CFA and secondly; we observe that in murine EAU, myeloid derived cells (part of the innate immune system) predominate throughout the course of disease (Kerr et al., 2008).

Additionally, the retina is endowed with myeloid-derived cells, microglia (Xu et al., 2007). Microglia are bone marrow derived cells that actively turnover (Kezic et al., 2008; Xu et al., 2007) and are under tonic suppressive control by the tissue, by cognate interaction with for example neuronal expression of CD200 and myeloid CD200R (Banerjee and Dick, 2004; Carter and Dick, 2004; Copland et al., 2007; Dick et al., 2001), sensing danger and maintaining tissue homeostasis.

How do resident or infiltrating myeloid-derived cells respond to the tissue infiltration of activated $\mathrm{T}$ cells that drive autoimmune responses in the retina? There is a paradox. Although during the course of rodent EAU we can suppress the tissue damage by regulating macrophage responses (Broderick et al., 2005; Copland et al., 2007; Copland et al., 2010) or via inhibiting TNF (Dick et al., 1996; Calder et al., 2005), T cells remain in the tissue and proliferate (Dick et al., 1998). If the autoimmune response remains incompletely regulated as it can be observed in the murine model, inflammation continues whereupon an altered phenotype of clinical disease persists for months with continued recruitment of myeloidderived cells that result in angiogenesis (Xu et al, Am. J. Pathol., In press).

Macrophages are currently defined according to their activation status as M1 and M2 (Gordon and Martinez, 2010; Gordon and Taylor, 2005). M1 macrophages are classical activated macrophages and in context of non-infectious uveitis, are presumed to be promoted in a TNF-dependent manner, by the IFN gamma release from the Th1 CD4+ T cell infiltrate during EAU. The cells are orchestrators of tissue damage mediated by the further release of pro-inflammatory cytokines (IL-1b, IL-6, TNF alpha), reactive oxygen species (ROS) and nitric oxide (Robertson et al., 2002; Liversidge et al., 2002). More recently however, we have observed that the infiltration of myeloid cells is indeed suppressive to $\mathrm{T}$ cell activation and proliferation, in a sense regulating the autoimmune response (Raveney et al., 2009; Raveney et al., 2010). Myeloid derived suppressor cells limit $\mathrm{T}$ cell activation and proliferation, and during EAU we observe that infiltrating myeloid cells also confer such phenotype. We are able to isolate such retinal infiltrating cells and they demonstrate a phenotype of $\mathrm{CD} 11 \mathrm{~b}+\mathrm{Gr} 1+\mathrm{Ly} 6 \mathrm{C}+\mathrm{CD} 31+$ and actively suppress $\mathrm{T}$ cell proliferation via both a nitric oxide, as previously shown in the rat (Liversidge et al., 2002), and prostaglandin mediated pathways to generate cells and implement regulatory function (Raveney et al., 2010).

Other retinal cell types are likely to play an equally important role in sensing and eliciting a response to danger and regulating the activation of autoreactive cells. Jiang et al. (2009) have for example described that TLR regulates the stimulatory effects of retinal astrocytes on retinal antigen specific T cells. TLR have also been described on retinal pigment 
epithelial (RPE) cells and it is suggested that their activation in those cells plays an important role in the regulation of innate but also adaptive immune response in the retina (Kumar et al, 2004). Similarly, Relvas et al. (2009) have shown that nucleotides stimulate cytokine production by RPE cells through P2Y receptors activation extending the concept towards endogenous danger signals.

\section{Conclusion}

Non-infectious uveitis is frequently referred as autoimmune. However, experimentally, noninfectious uveitis requires concomitant and initial activation of innate immunity prior to generation of specific $\mathrm{T}$ cell responses. Therefore, clinically, one notion is that even in autoimmune models there is a requisite for both innate immunity (autoinflammation) as well as autoimmunity (antigen-specific $\mathrm{T}$ cell mediated) to generate full clinical expression of disease. Genetic and immunological data strongly support such a notion, and in man, autoimmune and autoinflammatory mechanisms participate independently as well as interdependently toward the development of many of the non infectious uveitic conditions. For example, based on our knowledge on the immunobiology and genetics of Blau's syndrome, one may postulate that autoinflammation plays a more pivotal role than autoimmunity in expression of uveitis associated with sarcoidosis, spondyloarthropathies (SPA) or inflammatory bowel disease (IBD). Since autoimmunity and autoinflammation evoke different molecular pathways, a better understanding of their respective roles in the development of uveitis will highlight treatment targets and bring greater understanding of immunity and inflammation that may be translated to other retinal diseases involving immune mediated mechanisms.

\section{Acknowledgments}

François Willermain is supported by the Fonds de la recherche en Ophthalmologie (FRO), the asbl Vésale, and grants from the FNRS.

JTR is supported by NIH grants EY019020, EY013093, and EY019604, as well as Research to Prevent Blindness, Fight for Sight, Oregon Clinical Trial Research Institute, William C. Kuzell Foundation, William and Mary Bauman Foundation, and Stan and Madelle Rosenfeld Family Trust.

ADD is supported from grants from National Eye Research Centre, Underwood Trust, Dunhill Medical Foundation and Department of Health's NIHR Biomedical Research Centre for Ophthalmology at Moorfields Eye Hospital and UCL Institute of Ophthalmology for human studies. The views expressed in the publication are those of the authors and not necessarily those of the Department of Health.

GW is supported by the Deusche Forschungsgemeinschaft through SFB 571.

\section{References}

Abu El-Asrar AM, Abouammoh M, Al-Mezaine HS. Tuberculous uveitis. Int. Ophthalmol. Clin. 2010; 50:19-39. [PubMed: 20375860]

Arostegui JI, Arnal C, Merino R, Modesto C, Antonia Carballo M, Moreno P, García-Consuegra J, Naranjo A, Ramos E, de Paz P, Rius J, Plaza S, Yagüe J. NOD2 gene-associated pediatric granulomatous arthritis: clinical diversity, novel and recurrent mutations, and evidence of clinical improvement with interleukin-1 blockade in a Spanish cohort. Arthritis Rheum. 2007; 56:38053813. [PubMed: 17968944]

Banerjee D, Dick AD. Blocking CD200-CD200 receptor axis augments NOS-2 expression and aggravates experimental autoimmune uveoretinitis in Lewis rats. Ocul. Immunol. Inflamm. 2004; 12:115-25. [PubMed: 15512981]

Billingham RE, Brent L, Medawar PB. Actively acquired tolerance of foreign cells. Nature. 1953; 172:603-6. [PubMed: 13099277] 
Broderick CA, Smith AJ, Balaggan KS, Georgiadis A, Buch PK, Trittibach PC, Barker SE, Sarra GM, Thrasher AJ, Dick AD, Ali RR. Local administration of an adeno-associated viral vector expressing IL-10 reduces monocyte infiltration and subsequent photoreceptor damage during experimental autoimmune uveitis. Mol. Ther. 2005; 123:69-73. Erratum in:2006. 13, 829.

Calder CJ, Nicholson LB, Dick AD. A selective role for the TNF p55 receptor in autocrine signaling following IFN-gamma stimulation in experimental autoimmune uveoretinitis. J. Immunol. 2005; 175:6286-93. [PubMed: 16272279]

Carter DA, Dick AD. CD200 maintains microglial potential to migrate in adult human retinal explant model. Curr. Eye. Res. 2004; 28:427-36. [PubMed: 15512951]

Casadevall A, Pirofski LA. Host-pathogen interactions: basic concepts of microbial commensalism, colonization, infection and disease. Infect. Immun. 2000; 68:6511-8. [PubMed: 11083759]

Caspi RR. A look at autoimmunity and inflammation in the eye. J. Clin. Invest. 2010; 120:3073-83. [PubMed: 20811163]

Caspi RR. Understanding autoimmune uveitis through animal models. The Friedenwald Lecture. Invest. Ophthalmol. Vis. Sci. 2011; 52:1872-9.

Chang JH, McCluskey PJ, Wakefield D. Toll-like receptors in ocular immunity and the immunopathogenesis of inflammatory eye disease. Br. J. Ophthalmol. 2006; 90:103-8. [PubMed: 16361678]

Chi ZL, Hayasaka Y, Zhang XY, Cui HS, Hayasaka S. S100A9-positive granulocytes and monocytes in lipopolysaccharide-induced anterior ocular inflammation. Exp. Eye. Res. 2007; 84:254-65. [PubMed: 17101129]

Colditz GA, Brewer TF, Berkey CS, Wilson ME, Burdick E, Fineberg HV, Mosteller F. Efficacy of BCG vaccine in the prevention of tuberculosis. Meta-analysis of the published literature. JAMA. 1994; 271:698-702. [PubMed: 8309034]

Cooper MD, Alder MN. The evolution of adaptive immune systems. Cell. 2006; 124:815-822. [PubMed: 16497590]

Copland DA, Calder CJ, Raveney BJ, Nicholson LB, Phillips J, Cherwinski H, Jenmalm M, Sedgwick JD, Dick AD. Monoclonal antibody-mediated CD200 receptor signaling suppresses macrophage activation and tissue damage in experimental autoimmune uveoretinitis. Am. J. Pathol. 2007; 171:580-8. [PubMed: 17600119]

Copland DA, Hussain K, Baalasubramanian S, Hughes TR, Morgan BP, Xu H, Dick AD, Nicholson LB. Systemic and local anti-C5 therapy reduces the disease severity in experimental autoimmune uveoretinitis. Clin. Exp. Immunol. 2010; 159:303-14. [PubMed: 20002447]

Cutrufello NJ, Karakousis PC, Fishler J, Albini TA. Intraocular tuberculosis. Ocul. Immunol. Inflamm. 2010; 18:281-291. [PubMed: 20662660]

Deeg CA, Raith AJ, Amann B, Crabb JW, Thurau SR, Hauck SM, Ueffing M, Wildner G, Stangassinger M. CRALBP is a highly prevalent autoantigen for human autoimmune uveitis. Clin. Dev. Immunol. 2007; 2007:39245. [PubMed: 18317528]

DeVoss J, Hou Y, Johannes K, Lu W, Liou GI, Rinn J, Chang H, Caspi RR, Fong L, Anderson MS. Spontaneous autoimmunity prevented by thymic expression of a single self-antigen. J. Exp. Med. 2006; 203:2727-35. [PubMed: 17116738]

Dick AD, McMenamin PG, Körner H, Scallon BJ, Ghrayeb J, Forrester JV, Sedgwick JD. Inhibition of tumor necrosis factor activity minimizes target organ damage in experimental autoimmune uveoretinitis despite quantitatively normal activated T cell traffic to the retina. Eur. J. Immunol. 1996; 26:1018-25. [PubMed: 8647162]

Dick AD, Duncan L, Hale G, Waldmann H, Isaacs J. Neutralizing TNF-alpha activity modulates T-cell phenotype and function in experimental autoimmune uveoretinitis. J. Autoimmun. 1998; 11:25564. [PubMed: 9693974]

Dick AD, Broderick C, Forrester JV, Wright GJ. Distribution of OX2 antigen and OX2 receptor within retina. Invest. Ophthalmol. Vis. Sci. 2001; 42:170-6. 2001. [PubMed: 11133863]

Dick AD, Okada AA, Forrrester JV. Practical Manual of Intraocular inflammation. Informa. 2008 ISBN: 978-084939183-5.

Dollfus H, Hafner R, Hofmann HM, Russo RA, Denda L, Gonzales LD, DeCunto C, Premoli J, MeloGomez J, Jorge JP, Vesely R, Stubna M, Dufier JL, Prieur AM. Chronic infantile neurological 
cutaneous and articular/neonatal onset multisystem inflammatory disease syndrome: ocular manifestations in a recently recognized chronic inflammatory disease of childhood. Arch. Ophthalmol. 2000; 118:1386-1392. [PubMed: 11030821]

Doycheva D, Pfannenberg C, Hetzel J, Deuter CM, Pavesio C, Kempf VA, Schuelen E, Aschoff P, Rao N, Zierhut M. Presumed tuberculosis-induced retinal vasculitis, diagnosed with positron emission tomography (18F-FDG-PET/CT), aspiration biopsy, and culture. Ocul. Immunol. Inflamm. 2010; 18:194-9. [PubMed: 20482398]

Dye C, Scheele S, Dolin P, Pathania V, Raviglione MC. Consensus statement. Global burden of tuberculosis: estimated incidence, prevalence, and mortality by country. WHO global surveillance and monitoring project. JAMA. 1999; 282:677-686. [PubMed: 10517722]

Erridge C. Endogenous ligands of TLR2 and TLR4: agonists or assistants? J. Leukoc. Biol. 2010; 87:989-99. [PubMed: 20179153]

Fang J, Fang D, Silver PB, Wen F, Li B, Ren X, Lin Q, Caspi RR, Su SB. The role of TLR2, TRL3, TRL4, and TRL9 signaling in the pathogenesis of autoimmune disease in a retinal autoimmunity model. Invest. Ophthalmol. Vis. Sci. 2010; 51:3092-9. [PubMed: 20107166]

Fine PE. Variation in protection by BCG: implications of and for heterologous immunity. Lancet. 1995; 346:1339-1345. [PubMed: 7475776]

Flynn J, Chan J. Tuberculosis: latency and reactivation. Infect. Immun. 2001; 69:4195-4201. [PubMed: 11401954]

Forrester JV, Worgul BV, Merriam GR Jr. Endotoxin-induced uveitis in the rat. Albrecht Von Graefes Arch. Klin. Exp. Ophthalmol. 1980; 213:221-33. [PubMed: 7006439]

Forrester JV, Xu H, Lambe T, Cornall R. Immune privilege or privileged immunity? Mucosal Immunol. 2008; 1:372-81. [PubMed: 19079201]

Forrester JV, Xu H, Kuffová L, Dick AD, McMenamin PG. Dendritic cell physiology and function in the eye. Immunol. Rev. 2010; 234:282-304. [PubMed: 20193026]

Friswell M, Campbell B, Rhodes J. The role of bacteria in the pathogenesis of inflammatory bowel disease. Gut Liver. 2010; 4:295-306. [PubMed: 20981205]

Fritz JH, Le Bourhis LL, Sellge G, Magalhaes JG, Fsihi H, Kufer TA, Collins C, Viala J, Ferrero RL, Girardin SE, Philpott DJ. Nod1-mediated innate immune recognition of peptidoglycan contributes to the onset of adaptive immunity. Immunity. 2007; 26:445-59. [PubMed: 17433730]

Garip A, Diedrichs-Möhring M, Thurau SR, Deeg CA, Wildner G. Uveitis in a patient treated with Bacille-Calmette-Guérin: possible antigenic mimicry of mycobacterial and retinal antigens. Ophthalmology. 2009; 116:2457-62. [PubMed: 19815288]

Geijtenbeek TBH, Gringhuis SJ. Signalling through C-type lectin receptors: shaping immune responses. Nat. Rev. Immunol. 2009; 9:465-479. [PubMed: 19521399]

Glocker EO, Hennigs A, Nabavi M, Schäffer AA, Woellner C, Salzer U, Pfeifer D, Veelken H, Warnatz K, Tahami F, Jamal S, Manguiat A, Rezaei N, Amirzargar AA, Plebani A, Hannesschläger N, Gross O, Ruland J, Grimbacher B. A homozygous CARD9 mutation in a family with susceptibility to fungal infections. N. Engl. J. Med. 2009; 361:1727-35. [PubMed: 19864672]

Gordon S, Taylor PR. Monocyte and macrophage heterogeneity. Nat. Rev. Immunol. 2005; 5:953-64. [PubMed: 16322748]

Gordon S, Martinez FO. Alternative activation of macrophages: mechanism and functions. Immunity. 2010; 32:593-604. [PubMed: 20510870]

Goriely S, Neurath MF, Goldman M. How microorganisms tip the balance between interleukin-12 family members. Nat. Rev. Immunol. 2008; 8:81-6. [PubMed: 18084185]

Gül A. Behçet's disease as an autoinflammatory disorder. Curr. Drug. Targets Inflamm. Allergy. 2005; 4:81-3. [PubMed: 15720240]

Guo P, Hirano MA, Herrin BR, Li J, Yu C, Sadlonova A, Cooper MD. Dual nature of the adaptive immune system in lampreys. Nature. 2009; 459:796-801. [PubMed: 19474790]

Gupta A, Bansal R, Gupta V, Sharma A, Bambery P. Ocular signs predictive of tubercular uveitis. Am. J. Ophthalmol. 2010; 149:562-70. [PubMed: 20149341]

Gupta V, Gupta A, Rao NR. Intraocular tuberculosis-an update. Surv. Ophthalmol. 2007; 52:561-587. [PubMed: 18029267] 
Hedrick SM. Immune system: not so superior. Science. 2009; 325:1623-1624. [PubMed: 19779174]

Hegde V, Dean F. Bilateral panuveitis and optic neuritis following Bacillus Calmette-Guerin (BCG) vaccination. Acta Paediatr. 2005; 94:635-636. [PubMed: 16188758]

Hirose S, Tanaka T, Nussenblatt RB, Palestine AG, Wiggert B, Redmond TM, Chader GJ, Gery I. Lymphocyte responses to retinal-specific antigens in uveitis patients and healthy subjects. Curr. Eye. Res. 1988; 7:393-402. [PubMed: 3371075]

Huerta C, Rivero E, Rodriguez LA. Incidence and risk factors for psoriasis in the general population. Arch. Dermatol. 2007; 143:1559-65. [PubMed: 18087008]

Jabs DA, Houk JL, Bias WB, Arnett FC. Familial granulomatous synovitis, uveitis, and cranial neuropathies. Am. J. Med. 1985; 78:801-804. [PubMed: 3993660]

Jabs DA, Nussenblatt RB, Rosenbaum JT, Standardization of Uveitis Nomenclature (SUN) Working Group. Standardization of uveitis nomenclature for reporting clinical data. Results of the First International Workshop. Am. J. Ophthalmol. 2005; 140:509-16. [PubMed: 16196117]

Janeway CA Jr. Approaching the asymptote? Evolution and revolution in immunology. Cold. Spring. Harb. Quant. Biol. 1989; 54:1-13.

Jiang G, Ke Y, Sun D, Wang Y, Kaplan HJ, Shao H. Regulatory role of TLR ligands on the activation of autoreactive T cells by retinal astrocytes. Invest. Ophthalmol. Vis. Sci. 2009; 50:4769-76. [PubMed: 19443727]

Kawai T, Akira S. The role of pattern-recognition receptors in innate immunity:update on toll-like receptors. Nat. Immunol. 2010; 11:373-383. [PubMed: 20404851]

Kerr EC, Copland DA, Dick AD, Nicholson LB. The dynamics of leukocyte infiltration in experimental autoimmune uveoretinitis. Prog. Retin. Eye. Res. 2008; 27:527-535. [PubMed: 18723108]

Kezic J, Xu H, Chinnery HR, Murphy CC, McMenamin PG. Retinal microglia and uveal tract dendritic cells and macrophages are not CX3CR1 dependent in their recruitment and distribution in the young mouse eye. Invest. Ophthalmol. Vis. Sci. 2008; 49:1599-608. [PubMed: 18385080]

Kezic J, Taylor S, Gupta S, Planck SR, Rosenzweig HL, Rosenbaum JT. Endotoxin-induced uveitis is primarily dependent on radiation-resistant cells and on MyD88 but not TRIF. J. Leukoc. Biol. 2011; 90:305-311. [PubMed: 21610198]

Khan AI, Heit B, Andonegui G, Colarusso P, Kubes P. Lipopolysaccharide: a p38 MAPK-dependent disrupter of neutrophil chemotaxis. Microcirculation. 2005; 12:421-32. [PubMed: 16020390]

Koizumi K, Poulaki V, Doehmen S, Welsandt G, Radetzky S, Lappas A, Kociok N, Kirchhof B, Joussen AM. Contribution of TNF-alpha to leukocyte adhesion, vascular leakage, and apoptotic cell death in endotoxin-induced uveitis in vivo. Invest. Ophthalmol. Vis. Sci. 2003; 44:2184-91. [PubMed: 12714660]

Kono H, Rock KL. How dying cells alert the immune system to danger. Nat. Rev. Immunol. 2008; 8:279-289. [PubMed: 18340345]

Kozhich AT, Chan CC, Gery I, Whitcup SM. Recurrent intraocular inflammation in endotoxin-induced uveitis. Invest. Ophthalmol. Vis. Sci. 2000; 41:1823-6. [PubMed: 10845604]

Krausgruber T, Blazek K, Smallie T, Alzabin S, Lockstone H, Sahgal N, Hussell T, Feldmann M, Udalova IA. IRF5 promotes inflammatory macrophage polarization and TH1-TH17 responses. Nat. Immunol. 2011; 2011(12):231-8. [PubMed: 21240265]

Kumar MV, Nagineni CN, Chin MS, Hooks JJ, Detrick B. Innate immunity in the retina: Toll-like receptor (TLR) signaling in human retinal pigment epithelial cells. J. Neuroimmunol. 2004; 153:7-15. [PubMed: 15265658]

Kurokawa T, Kikuchi T, Ohta K, Imai H, Yoshimura N. Ocular manifestations in Blau syndrome associated with a CARD15/Nod2 mutation. Ophthalmology. 2003; 110:2040-2044. [PubMed: 14522785]

Lambe T, Leung JC, Ferry H, Bouriez-Jones T, Makinen K, Crockford TL, Jiang HR, Nickerson JM, Peltonen L, Forrester JV, Cornall RJ. Limited peripheral T cell anergy predisposes to retinal autoimmunity. J. Immunol. 2007; 178:4276-83. [PubMed: 17371984]

Latkany PA, Jabs DA, Smith JR, Rosenbaum JT, Tessler H, Schwab IR, Walton RC, Thorne JE, Maguire AM. Multifocal choroiditis in patients with familial juvenile systemic granulomatosis. Am. J. Ophthalmol. 2002; 134:897-904. [PubMed: 12470760] 
Lee RW, Dick AD. Treat early and embrace the evidence in favour of anti-TNF-alpha therapy for Behçet's uveitis. Br. J. Ophthalmol. 2010; 94:269-70. [PubMed: 20215370]

Lee YK, Mazmanian SK. Has the microbiota played a critical role in the evolution of the adaptive immune system? Science. 2010; 330:1768-1773. [PubMed: 21205662]

Liberek A, Korzon M, Bernatowska E, Kurenko-Deptuch M, Rytlewska M. Vaccination-related Mycobacterium bovis BCG infection. Emerg. Infect. Dis. 2006; 12:860-862. [PubMed: 16710956]

Liversidge J, Dick A, Gordon S. Nitric oxide mediates apoptosis through formation of peroxynitrite and Fas/Fas-ligand interactions in experimental autoimmune uveitis. Am. J. Pathol. 2002; 160:905-16. [PubMed: 11891189]

Maartens G, Wilkinson RJ. Tuberculosis. Lancet. 2007; 370:2030-2043. [PubMed: 17719083]

Market E, Papavasilliou N. VDJ recombination and the evolution of the adaptive immune system. Plos Biol. 2003:24-26.

Martin TM, Kurz DE, Rosenbaum JT. Genetics of uveitis. Ophthalmol. Clin. North. Am. 2003; 16:555-65. [PubMed: 14740996]

Masters SL, Simon A, Aksentijevich I, Kastner DL. Horror autoinflammaticus: the molecular pathophysiology of autoinflammatory disease. Annu. Rev. Immunol. 2009; 27:621-68. [PubMed: 19302049]

Mattapallil MJ, Silver PB, Mattapallil JJ, Horai R, Karabekian Z, McDowell JH, Chan CC, James EA, Kwok WW, Sen HN, Nussenblatt RB, David CS, Caspi RR. Uveitis-Associated Epitopes of Retinal Antigens Are Pathogenic in the Humanized Mouse Model of Uveitis and Identify Autoaggressive T Cells. J. Immunol. 2011; 187:1977-1985. [PubMed: 21765017]

Matzinger P. Tolerance, danger, and the extended family. Annu. Rev. Immunol. 1994; 12:991-1045. [PubMed: 8011301]

Matzinger P, Kamala T. Tissue-based class control: the other side of tolerance. Nat. Rev. Immunol. 2011; 11:221-30. [PubMed: 21350581]

McMenamin PG, Crewe J, Morrison S, Holt PG. Immunomorphologic studies of macrophages and MHC class II-positive dendritic cells in the iris and ciliary body of the rat, mouse, and human eye. Invest. Ophthalmol. Vis. Sci. 1994; 35:3234-50. [PubMed: 8045716]

Medzhitov R, Janeway CA. Innate immunity: the virtues of a nonclonal system of recognition. Cell. 1997; 91:295-298. [PubMed: 9363937]

Miceli-Richard C, Lesage S, Rybojad M, Prieur AM, Manouvrier-Hanu S, Häfner R, Chamaillard M, Zouali H, Thomas G, Hugot JP. CARD15 mutations in Blau syndrome. Nat. Genet. 2001; 29:1920. [PubMed: 11528384]

Mizuki N, Meguro A, Ota M, Ohno S, Shiota T, Kawagoe T, Ito N, Kera J, Okada E, Yatsu K, Song YW, Lee EB, Kitaichi N, Namba K, Horie Y, Takeno M, Sugita S, Mochizuki M, Bahram S, Ishigatsubo Y, Inoko H. Genome-wide association studies identify IL23R-IL12RB2 and IL10 as Behçet's disease susceptibility loci. Nat. Genet. 2010; 42:703-6. [PubMed: 20622879]

Neven B, Marvillet I, Terrada C, Ferster A, Boddaert N, Couloignier V, Pinto G, Pagnier A, Bodemer C, Bodaghi B, Tardieu M, Prieur AM, Quartier P. Long-term efficacy of the interleukin-1 receptor antagonist anakinra in ten patients with neonatal-onset multisystem inflammatory disease/chronic infantile neurologic, cutaneous, articular syndrome. Arthritis Rheum. 2010; 62:258-267. [PubMed: 20039428]

Noah PW. The role of microorganisms in psoriasis. Semin Dermatol. 1990; 9:269-76. [PubMed: 2285571]

Nussenblatt RB, Gery I, Ballintine EJ, Wacker WB. Cellular immune responsiveness of uveitis patients to retinal S-antigen. Am. J. Ophthalmol. 1980; 89:173-9. [PubMed: 7355973]

O'Neill LA. Primer: Toll-like receptor signaling pathways--what do rheumatologists need to know? Nat. Clin. Pract. Rheumatol. 2008; 4:319-27. [PubMed: 18446139]

Opremcak EM, Cowans AB, Orosz CG, Adams PW, Whisler RL. Enumeration of autoreactive helper T lymphocytes in uveitis. Invest Ophthalmol Vis Sci. 1991; 32:2561-7. [PubMed: 1831187]

Palm NW, Medzitov R. Pattern recognition receptors and control of adaptive immunity. Immunol. Rev. 2009; 227:221-233. [PubMed: 19120487] 
Petty RE, Johnston W, McCormick AQ, Hunt DWC, Rootman J, Rollins DF. Uveitis and arthritis induced by adjuvant: Clinical, immunologic and histologic characteristics. J. Rheumatol. 1989; 16:499-505. [PubMed: 2664171]

Pointon JJ, Harvey D, Karaderi T, Appleton LH, Farrar C, Stone MA, Sturrock RD, Brown MA, Wordsworth BP. Elucidating the chromosome 9 association with AS; CARD9 is a candidate gene. Genes Immun. 2011; 12:319-20.

Raveney BJ, Copland DA, Dick AD, Nicholson LB. TNFR1-dependent regulation of myeloid cell function in experimental autoimmune uveoretinitis. J Immunol. 2009; 183:2321-9. [PubMed: 19635911]

Raveney BJ, Copland DA, Calder CJ, Dick AD, Nicholson LB. TNFR1 signalling is a critical checkpoint for developing macrophages that control of T-cell proliferation. Immunology. 2010; 131:340-9. [PubMed: 20518824]

Relvas LJ, Bouffioux C, Marcet B, Communi D, Makhoul M, Horckmans M, Blero D, Bruyns C, Caspers L, Boeynaems JM, Willermain F. Extracellular nucleotides and interleukin-8 production by ARPE cells: potential role of danger signals in blood-retinal barrier activation. Invest. Ophthalmol. Vis. Sci. 2009; 2009(50):1241-6. [PubMed: 19029040]

Remmers EF, Cosan F, Kirino Y, Ombrello MJ, Abaci N, Satorius C, Le JM, Yang B, Korman BD, Cakiris A, Aglar O, Emrence Z, Azakli H, Ustek D, Tugal-Tutkun I, Akman-Demir G, Chen W, Amos CI, Dizon MB, Kose AA, Azizlerli G, Erer B, Brand OJ, Kaklamani VG, Kaklamanis P, Ben-Chetrit E, Stanford M, Fortune F, Ghabra M, Ollier WE, Cho YH, Bang D, O'Shea J, Wallace GR, Gadina M, Kastner DL, Gül A. Genome-wide association study identifies variants in the MHC class I, IL10, and IL23R-IL12RB2 regions associated with Behçet's disease. Nat. Genet. 2010; 42:698-702. [PubMed: 20622878]

Robertson MJ, Erwig LP, Liversidge J, Forrester JV, Rees AJ, Dick AD. Retinal microenvironment controls resident and infiltrating macrophage function during uveoretinitis. Invest. Ophthalmol. Vis. Sci. 2002; 43:2250-7. [PubMed: 12091424]

Rodrigues LC, Diwan VK, Wheeler JG. Protective effect of BCG against tuberculous meningitis and miliary tuberculosis: a meta-analysis. Int. J. Epidemiol. 1993; 22:1154-1158. [PubMed: 8144299]

Ronald PC, Beutler B. Plant and animal sensors of conserved microbial signatures. Science. 2010; 330:1061-1064. [PubMed: 21097929]

Rosenbaum JT, McDevitt HO, Guss RB, Egbert PR. Endotoxin-induced uveitis in rats as a model for human disease. Nature. 1980; 286:611-3. [PubMed: 7402339]

Rosenbaum JT, Woods A, Kezic J, Planck SR, Rosenzweig HL. Contrasting ocular effects of local versus systemic endotoxin. Invest. Ophthalmol. Vis. Sci. 2011 2011-epub.

Rosenzweig HL, Martin TM, Planck SR, Galster K, Jann MM, Davey MP, Kobayashi K, Flavell RA, Rosenbaum JT. Activation of NOD2 in vivo induces IL-1 beta production in the eye via caspase-1 but results in ocular inflammation independently of IL-1 signaling. J. Leukoc. Biol. 2008; 84:529_ 36. [PubMed: 18495787]

Rosenzweig HL, Galster K, Planck S, Rosenbaum JT. NOD1 expression in the eye and functional contribution to IL-1 $\{$ beta\} dependent ocular inflammation in mice. Invest. Ophthalmol. Vis. Sci. 2009; 50:1746-53. [PubMed: 19074813]

Schroder K, Tschopp J. The inflammasomes. Cell. 2010; 140:821-831. [PubMed: 20303873]

Shakeel A, Gouws P. Muckle-Wells syndrome: another cause of acute anterior uveitis. Eye. 2007; 21:849-850. [PubMed: 17277755]

Silva LC, Ortigosa LC, Benard G. Anti-TNF- $\alpha$ agents in the treatment of immune-mediated inflammatory diseases: mechanisms of action and pitfalls. Immunotherapy. 2010; 2:817-33. [PubMed: 21091114]

Song Z, Marzilli L, Greenlee BM, Chen ES, Silver RF, Askin FB, Teirstein AS, Zhang Y, Cotter RJ, Moller DR. Mycobacterial catalase-peroxidase is a tissue antigen and target of the adaptive immune response in systemic sarcoidosis. J. Exp. Med. 2005; 201:755-67. [PubMed: 15753209]

Strober W. Inside the microbial and immune labyrinth: Gut microbes: friends or fiends? Nat. Med. 2010; 16:1195-7. [PubMed: 21052070] 
Su SB, Silver PB, Grajewski RS, Agarwal RK, Tang J, Chan CC, Caspi RR. Essential role of the MyD88 pathway, but nonessential roles of TLRs 2, 4, and 9, in the adjuvant effect promoting Th1-mediated autoimmunity. J. Immunol. 2005; 175:6303-10. [PubMed: 16272281]

Takeuchi M, Usui Y, Okunuki Y, Zhang L, Ma J, Yamakawa N, Hattori T, Kezuka T, Sakai J, Goto H. Immune responses to interphotoreceptor retinoid-binding protein and S-antigen in Behcet's patients with uveitis. Invest. Ophthalmol. Vis. Sci. 2010; 51:3067-75. [PubMed: 20089879]

Tamissia N, LeMoigne V, Calzetti F, Donini M, Gasperini S, Ear T, Cloutier A, Martinez FO, Fabbri M, Locati M, Mantovani A, McDonald PP, Cassatella MA. The MyD88-independent pathway is not mobilized in human neutrophils stimulated via TLR4. J. Immunol. 2007; 178:7344-56. [PubMed: 17513785]

Taurog JD, Richardson JA, Croft JT, Simmons WA, Zhou M, Fernández-Sueiro JL, Balish E, Hammer RE. The germfree state prevents development of gut and joint inflammatory disease in HLA-B27 transgenic rats. J. Exp. Med. 1994; 180:2359-64. [PubMed: 7964509]

Teoh SC, Sharma S, Hogan A, Lee R, Ramanan AV, Dick AD. Tailoring biological treatment: anakinra treatment of posterior uveitis associated with the CINCA syndrome. Br. J. Ophthalmol. 2007; 91:263-4. [PubMed: 17244662]

Terrada C, Neven B, Boddaert N, Souied EH, Prieur AM, Quartier P, Lehoang P, Bodaghi B. Ocular modifications in a young girl with cryopyrin-associated periodic syndromes responding to interleukin-1 receptor antagonist anakinra. J. Ophthalmic. Inflamm. Infect. Apr 9.2011 Epub ahead of print.

Uppal GS, Shah AN, Tossounis CM, Tappin MJ. Bilateral panuveitis following intravesical BCG immunotherapy for bladder carcinoma. Ocul. Immunol. Inflamm. 2010; 18:292-296. [PubMed: 20662661]

Wacker WB, Lipton MM. Experimental allergic uveitis: homologous retina as uveitogenic antigen. Nature. 1965; 206:253-4. [PubMed: 5836315]

Wacker WB. Proctor Lecture. Experimental allergic uveitis. Investigations of retinal autoimmunity and the immunopathologic responses evoked. Invest. Ophthalmol. Vis. Sci. 1991; 32:3119-28. [PubMed: 1721045]

Wallace GR, Niemczyk E. Genetics in ocular inflammation--basic principles. Ocul. Immunol. Inflamm. 2011; 19:10-8. [PubMed: 21250923]

Weaver CT, Hatton RD. Interplay between the Th17 and T reg cell lineages: a co-evolutionary perspective. Nat. Rev. Immunol. 2009; 9:883-889. [PubMed: 19935807]

Wildner G, Diedrichs-Mohring M. Autoimmune uveitis induced by molecular mimicry of peptides from rotavirus, bovine casein and retinal S-antigen. Eur. J. Immunol. 2003; 33:2577-2587. [PubMed: 12938234]

Wildner G, Diedrichs-Moehring M. Autoimmune uveitis and antigenic mimicry of environmental antigens. Autoimmun. Rev. 2004; 3:383-387. [PubMed: 15288005]

Wildner G, Diedrichs-Moehring M. Multiple autoantigen mimotopes of infectious agents induce autoimmune arthritis and uveitis in lewis rats. Clin. Diagn. Lab. Immunol. 2005; 12:677-679. [PubMed: 15879033]

Wilson ME, Fineberg HV, Colditz GA. Geographic latitude and the efficacy of bacillus CalmetteGuerin vaccine. Clin. Infect. Dis. 1995; 20:982-991. [PubMed: 7795103]

Woods AC. Studies on the actions of toxins and protein degeneration products on the eye. Arch. Ophthalmol. 1916; 45:451-64.

$\mathrm{Xu}$ H, Chen M, Mayer EJ, Forrester JV, Dick AD. Turnover of resident retinal microglia in the normal adult mouse. Glia. 2007; 55:1189-98. [PubMed: 17600341]

Yamamoto JH, Minami M, Inaba G, Masuda K, Mochizuki M. Cellular autoimmunity to retinal specific antigens in patients with Behçet's disease. Br. J. Ophthalmol. 1993; 77:584-9. [PubMed: 8218058]

Yanagihori H, Oyama N, Nakamura K, Mizuki N, Oguma K, Kaneko F. Role of IL-12B promoter polymorphism in Adamantiades-Behcet's disease susceptibility: An involvement of Th1 immunoreactivity against Streptococcus Sanguinis antigen. J. Invest. Dermatol. 2006; 126:1534 40. [PubMed: 16514412] 
Yu JR, Leslie KS. Cryopyrin-associated periodic syndrome: an update on diagnosis and treatment response. Curr. Allergy. Asthma. Rep. 2011; 11:12-20. [PubMed: 21104172]

Zhernakova A, Festen EM, Franke L, Trynka G, van Diemen CC, Monsuur AJ, Bevova M, Nijmeijer RM, van 't Slot R, Heijmans R, Boezen HM, van Heel DA, van Bodegraven AA, Stokkers PC, Wijmenga C, Crusius JB, Weersma RK. Genetic analysis of innate immunity in Crohn's disease and ulcerative colitis identifies two susceptibility loci harboring CARD9 and IL18RAP. Am. J. Hum. Genet. 2008; 82:1202-10. [PubMed: 18439550] 


\section{Host-microbe interaction}

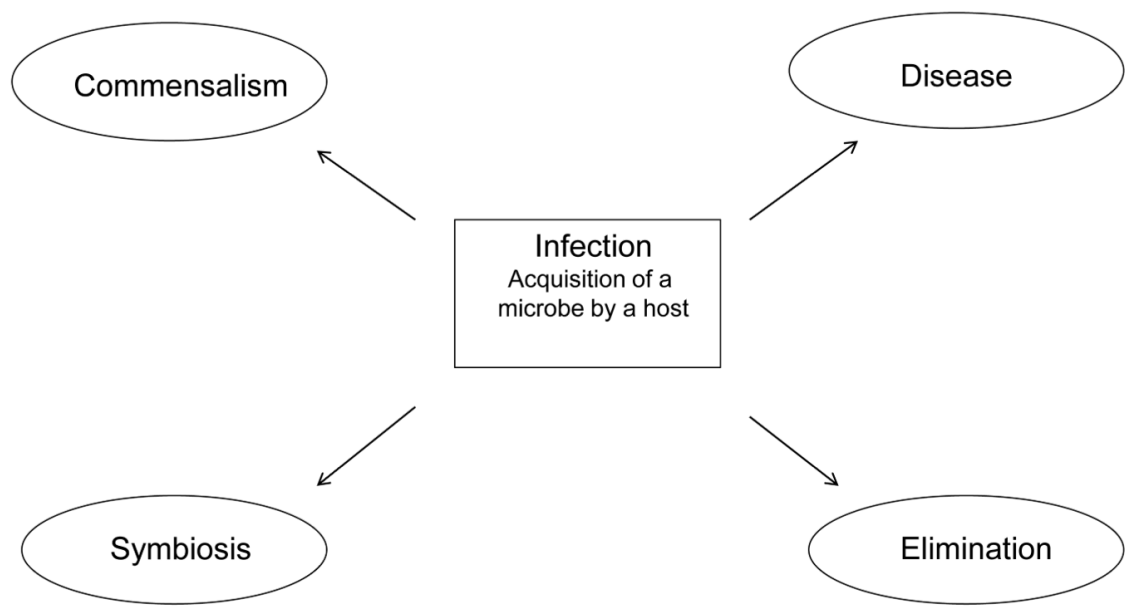

Figure 1. Host-microbe interactions

Infection can be defined as the acquisition of a microbe by a host (Casadevall and Pirofski, 2000). Most frequently, microbial colonization occurs without ill effect and indeed then contributes to benefit for the host. 


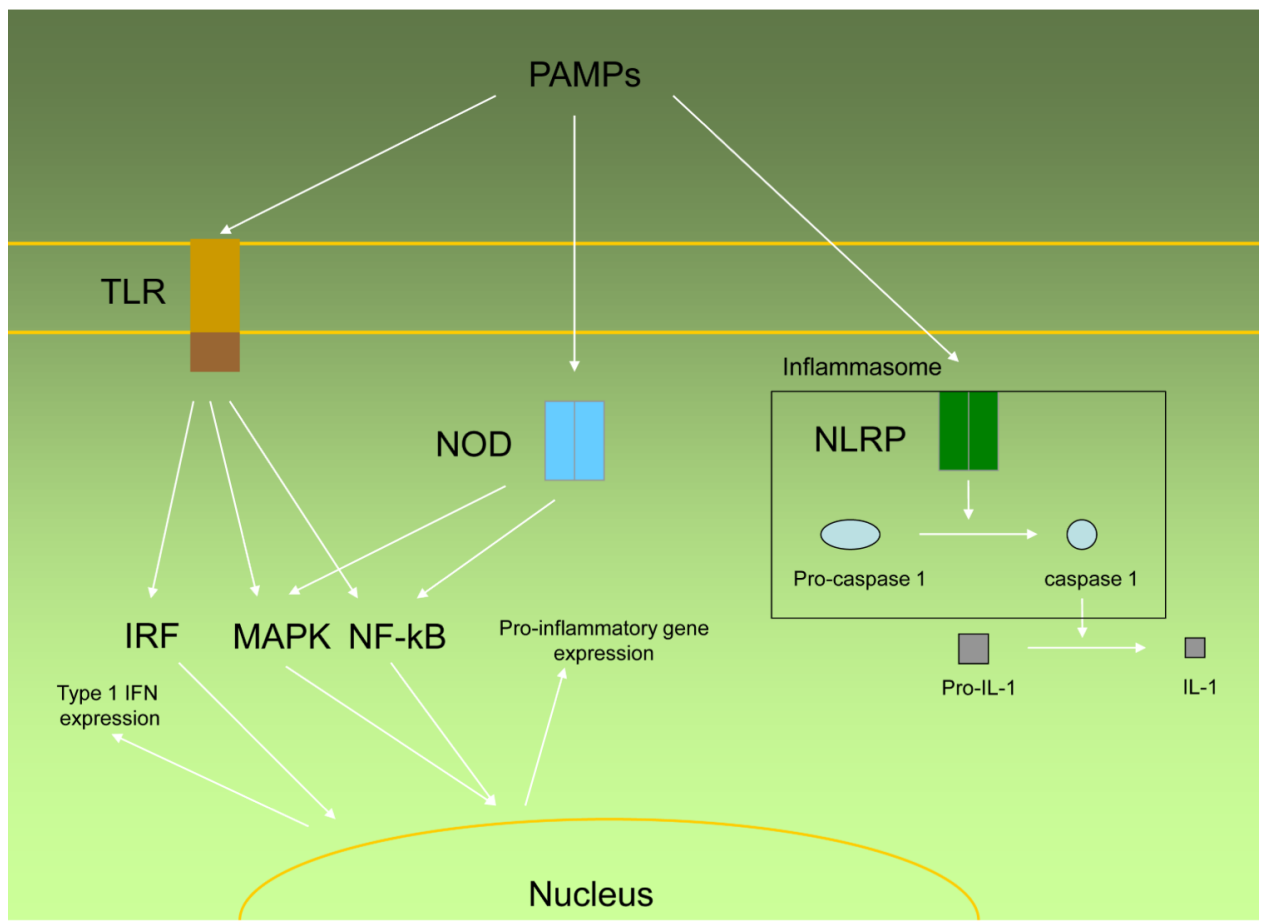

Figure 2. PAMPs receptors and their signaling pathways

The cell detects the presence of microbes via PAMPs receptors. Toll-like receptors (TLR) and C-type lectins (not depicted) are expressed on plasma membranes and endosomes while RNA and DNA sensors (not depicted) are present in the cytoplasm. TLR stimulation activates NF-kB and MAPK pathways driving proinflammatory cytokines cascades. Transcription of members of the interferon regulatory factor (IRF) is also central features of this series of receptors. IRF have DNA binding domains and in part activates the transcription of type I interferons as well as other interferon induced genes. Intracellular pathogens are also detected by NOD-like receptors. Upon activation, NOD1 and NOD2 oligomerise and activate the NF-kB and MAPK pathways. Activation of NLRP induces the formation of large scaffolds of proteins, called inflammasomes, which will activate caspase- 1 and promote the maturation (and secretion) of interleukin-1beta (IL-1b) and IL-18. 


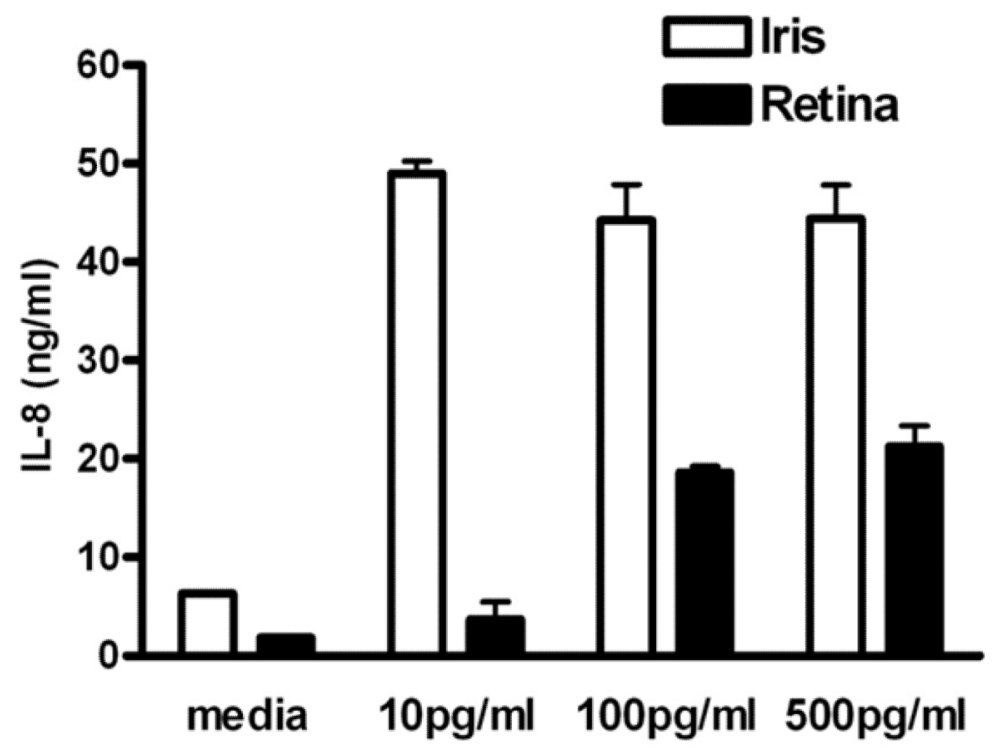

Figure 3. Human iris and retina synthesize IL-8 in response to LPS

Human iris or retina explants (cultured from a $6 \mathrm{~mm}$ punch biopsy) were stimulated with the indicated concentrations of LPS (purified from E. Coli 0111:B4 and purchased from Sigma Chemicals). IL- 8 production in the supernatant was quantified by ELISA at $24 \mathrm{~h}$ post stimulation. Data are represented as mean + s.e.m. of 2 different eyes performed in triplicates. Experiment has been repeated 3 individual times. 


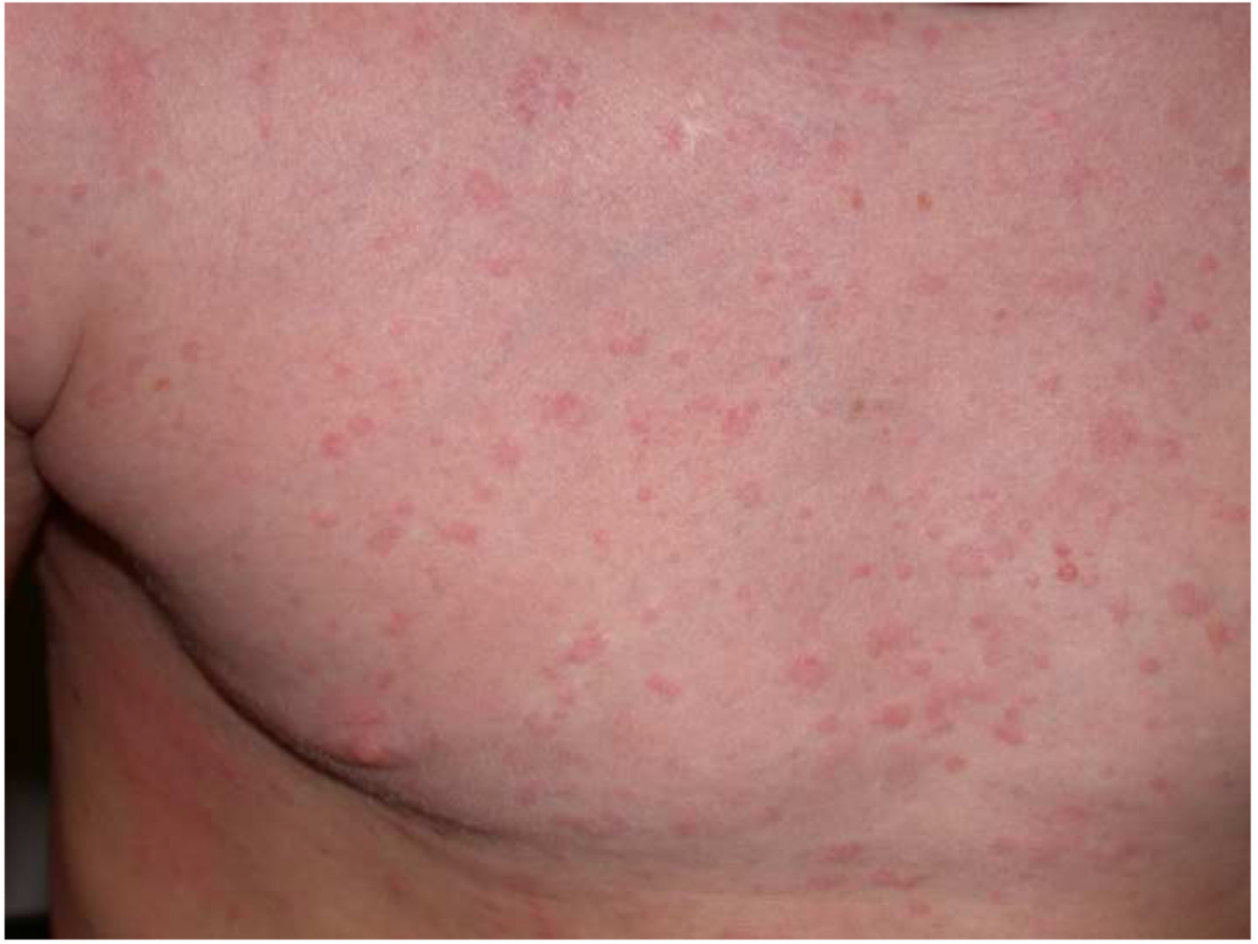

Figure 4. Chronic urticaria in a child with CINCA syndrome 
a
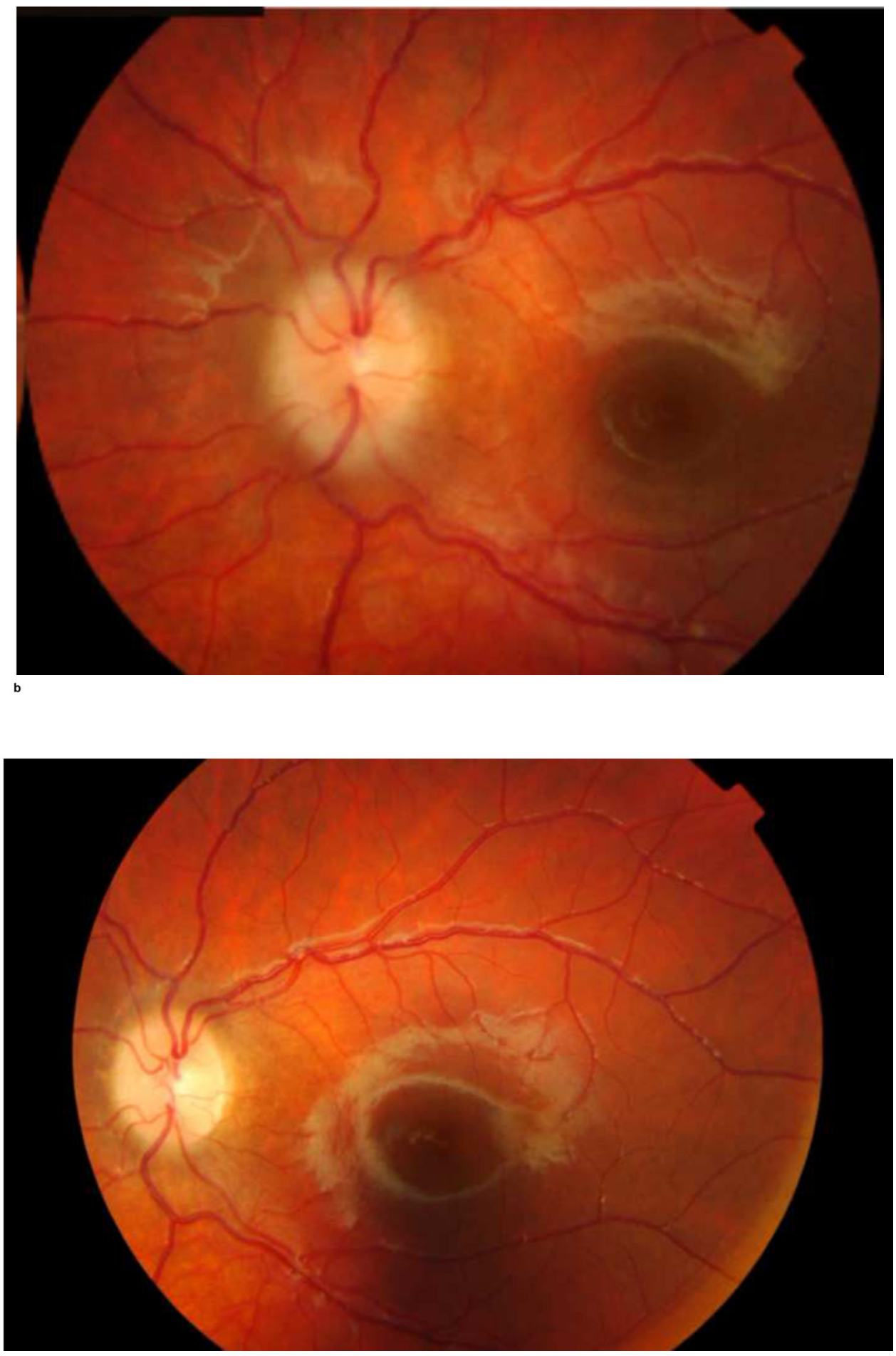

Figure 5. Swollen optic disc in a child with CINCA syndrome

a. Before treatment with anti-IL1 inhibitors

b. After treatment with anti-IL1 inhibitors 


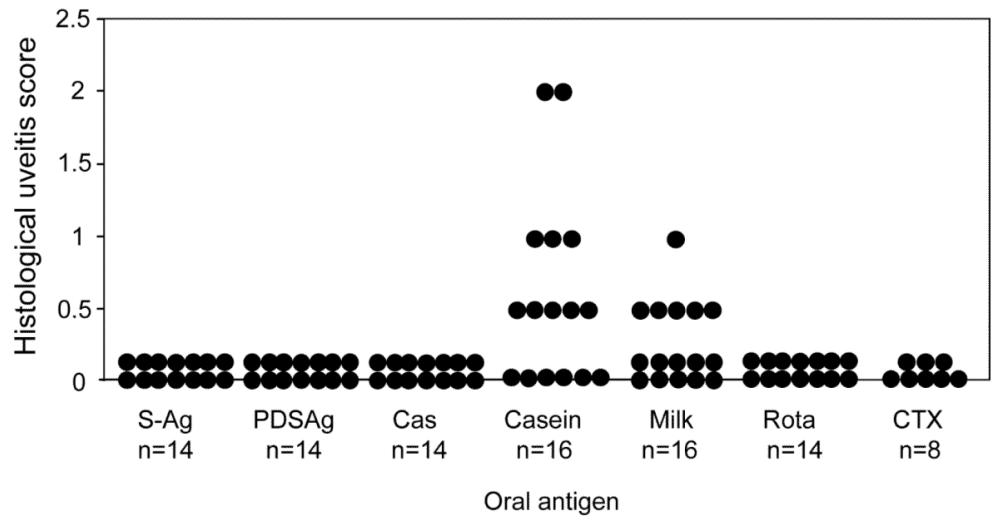

Figure 6. Induction of uveitis by oral immunization

Lewis rats were fed once with $1 \mathrm{mg}$ of either protein (S-Ag: retinal S-Antigen; Casein: bovine aS1 and aS2 casein) or peptide (PDSAg: aa 342-354 from S-Ag; Cas: aa 73-84 from bovine aS2 casein; Rota: aa 501-602 from rotavirus outer capsid protein vp4), or 0,5ml fatreduced bovine milk, all mixed with $10 \mathrm{mg}$ Cholera toxin (CTX), feeding CTX alone was used as a control. Uveitis was determined by histology of rat eyes. $\mathrm{N}=$ number of eyes. Purified casein contains less than $20 \%$ aS2 casein (180 mg aS2 casein in $1 \mathrm{mg}$ casein), and $0,5 \mathrm{ml}$ bovine milk contains about $1,4 \mathrm{mg}$ aS2 casein. 
Table 1

Pathogen associated molecular patterns receptors

\begin{tabular}{cl}
\hline \multicolumn{2}{c}{ PAMPs receptors } \\
\hline Family & Cellular location \\
\hline Toll like receptors (TLRs) & $\begin{array}{c}\text { Plasma membranes and } \\
\text { endosomes }\end{array}$ \\
$\begin{array}{c}\text { C-type lectins (CTLs) } \\
\text { Retinoic acid-inducible gene } \\
\text { (RIG-I)-like helicase (RLHs) }\end{array}$ & Plasma membrane \\
NOD-like receptors (NLRs) & Cytoplasmic
\end{tabular}

Prog Retin Eye Res. Author manuscript; available in PMC 2013 March 1. 
Table 2

Autoinflammatory syndromes.

\begin{tabular}{|c|c|}
\hline Auto inflammatory syndrome & Associated gene \\
\hline Blau syndrome & $\begin{array}{l}\text { nucleotide oligomerization domain } 2 \\
\text { (NOD2) }\end{array}$ \\
\hline $\begin{array}{l}\text { CAPS (Cryopyrin-associated periodic syndrome) } \\
\text { Familial Cold Urticaria Muckle-Wells syndrome } \\
\text { Chronic Infantile Neurologic Cutaneous and Articular } \\
\text { syndrome (CINCA) / NOMID }\end{array}$ & $\begin{array}{l}\text { Cold-Induced Autoinflammatory Syndrome } \\
1 \text { (CIAS1) gene ( also known as the NLRP3, } \\
\text { NALP3 or PYPAF1 gene) }\end{array}$ \\
\hline TNF receptor associated periodic syndrome (TRAPS) & TNF $\alpha$ receptor 1 (TNFRSF1A) \\
\hline Mevalonate kinase deficiency & Mevalonate kinase \\
\hline $\begin{array}{l}\text { Periodic fever, aphthous stomatitis, pharyngitis and } \\
\text { adenitis (PFAPA syndrome) }\end{array}$ & Unknown \\
\hline Familial Mediterranean fever & MEFV (Mediterranean fever) \\
\hline $\begin{array}{l}\text { Pyogenic sterile arthritis, pyoderma gangrenosum, } \\
\text { acne (PAPA) }\end{array}$ & $\mathrm{CD} 2$ binding protein 1 (CD2BP1) \\
\hline $\begin{array}{l}\text { Deficiency of the interleukin-1-receptor } \\
\text { antagonist (DIRA) }\end{array}$ & IL-1 receptor antagonist \\
\hline
\end{tabular}


Table 3

Common ocular findings in patients with autoinflammatory syndromes.

\begin{tabular}{|l|l|}
\hline Blau syndrome & Anterior and posterior uveitis \\
& Multifocal choroiditis \\
Cataract \\
Band keratopathy \\
& Corneal stromal opacities \\
& Glaucoma \\
& Macular edema \\
& Optic disc swelling \\
& Anterior ischemic optic neuropathy \\
\hline Muckle-Wells syndrome & Conjunctivitis \\
\hline CINCA/NOMID syndrome & Papillitis, papilledema, optic atrophy \\
& Anterior uveitis \\
& Chronic conjunctivitis \\
& Band keratopathy \\
& Stromal keratitis \\
& Retinal vasculitis \\
& Macular edema \\
\hline
\end{tabular}

